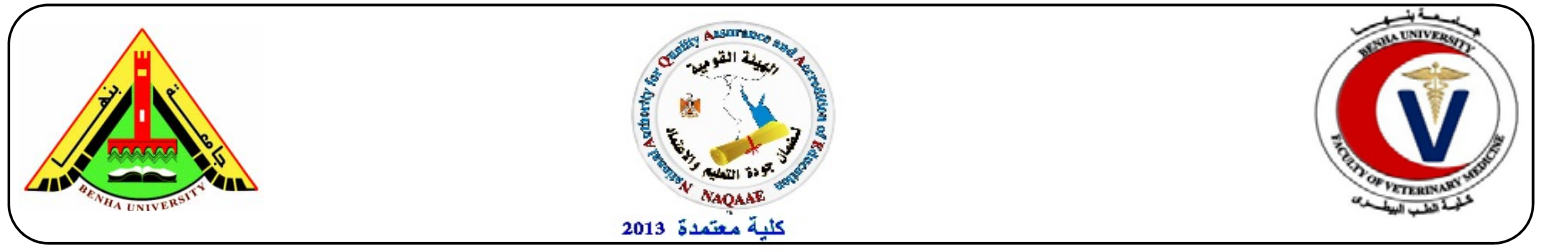

\title{
Protective and treatment effect of garlic extract on biochemical changes induced by pesticides in rats
}

\author{
Omayma, A. R. Abouzaid, Afaf D. Abd El-Mageid and Emad A. Alsadek \\ Faculty of Veterinary Medicine, Department of Biochemistry, Moshtohor, Benha University, \\ Egypt.
}

\begin{abstract}
A B S T R A C T
The present study was undertaken to evaluate the possible protective and treatment influence of garlic extract supplementation to improve hepato-renal functions and antioxidant system against lambadacyhalothrin and thiodicarb pesticides intoxicated rats have been evaluated. This study was carried out on seventy male rats randomly divided into seven equal groups. Blood samples and liver tissues specimens were collected from all animal groups and used for determination of (SOD, CAT and GSH) in liver tissues. Also serum ALT, AST, GGT, albumin, total protein, creatinine and urea were also determined. The obtained results revealed that thiodicarb and lambada-cyhalothrin induced a decrease in antioxidant enzyme activities in liver tissue. Also depletion in serum albumin, total protein. Moreover, administration of thiodicarb and lambada-cyhalothrin exhibited increase in serum ALT, AST, GGT activities, creatinine and urea concentration. While administration of garlic extract to pesticides intoxicated rats showed a significant increase in GSH, CAT, SOD, Total protein and Albumin and markedly decrease in ALT,AST and GGT activity, creatinine and urea concentration. This study provides in vivo evidence that garlic constitutes a powerful antioxidant property that was able to improve the adverse biochemical changes induced by carbamates and pyrethroids compounds in rats that are widely used in our country. This protective effect of garlic extract dampen the toxicity of thiodicarb and lambada-cyhalothrin intoxicated rats; therefore might be due to its powerful antioxidant activity.
\end{abstract}

Keywords: Garlic extract, Pesticides, hepato-renal functions, antioxidants, enzymes.

(http://www.bvmj.bu.edu.eg)

(BVMJ-29(1): 205-213, 2015)

\section{INTRODUCTION}

$\mathrm{P}$ esticides are used extensively in agriculture to enhance food production by eradicating unwanted insects and controlling disease vectors (Aslan et al., 2009). The unregulated use and its aerial application over large agricultural and urban areas have caused severe environmental pollution and potential health hazards. Carbamats and pyrethroids compounds are widely used and include some of the most toxic chemical agents. Recently different types of these pesticides have been synthesized and are extensively used worldwide in agriculture and public health programs as insecticides, acaricides and nematicides, in veterinary medicine as ectoparasiticides (Balali-Mood et al., 2008). Exposure to low-level of pesticides is known to produce a variety of biochemical changes, some of which may be responsible for the adverse biological effects reported in human and experimental animals studies. Conversely, some biochemical alterations may not necessarily lead to clinically recognizable symptoms, although all the biochemical responses can be used as markers of exposure or effect. The biochemical changes induced after exposure to pesticides or their active metabolites include target cell/receptor binding, protein and DNA adduct formation, and induction or inhibition of 
enzymes. Oxidative stress can also be induced by pesticides, either by overproduction of free radicals or by alteration in antioxidant defense mechanisms, including detoxification and scavenging enzymes (Abdollahiet al., 2004). There have been great efforts to find safe and potent natural antioxidants from various plant sources. As harmless sources of antioxidants, wild herbs, spices, fruits, nuts, and leafy vegetables have been investigated, for their antioxidant properties. The increasing interest in natural dietary components has focused attention on plants used as food or spices, which are a rich source of bionutrients or bio-active phytochemicals. Fresh garlic is reportedly famous for its anti-toxic, antimutagenic and anticarcinogenic effects due to the presence of sulfhydryl compounds and other organosulfur compounds; such as diallyl sulphide (DAS), diallyl disulphide (DADS), ajoene, allixin, allylmercaptans and allylmethyl sulphides (Borek, 2001).Accordingly, the aim of the present study was to evaluate the protective and treatment effect of garlic extract in thiodicarb and lambada-cyhalothjrin intoxicated rats.

\section{MATERIALS AND METHODS}

\subsection{Animals}

Seventy male waster rats of apparently healthy and sexually mature (10-11 weeks old) were used in this study. The animals were obtained from laboratory animal house of Modern Veterinary Office, GizaEgypt. Animals were kept under full hygienic conditions provided with free access of fresh water and standard balanced diet, and left under supervision for one week for acclimization before the beginning of experimental work. The animals used in the study is conformed to the guidelines and bioethics of The Egyptian Scientific Research Academy that coincide well with the National Institute of Health (NIH) Guidelines.

\subsection{Pesticides}

The pesticides compounds used in the present study were

Thiodicarb, Lambada-cyhalothrin were bought from the Egyptian market and manufactured by kafr Alzyat pesticides and chemicals company.

\subsection{Garlic extract}

A preparation of whole crude garlic aqueous extract was carried out as follows: Fresh peeled cloves of garlic (Allium sativum, purchased from Egyptian native market) sliced into small pieces and ground in a clean mortar using a mortar pestle to produce a fine paste. The working solution was then prepared by dissolving $2 \mathrm{~g}$ of the paste in $100 \mathrm{ml}$ of distilled water, where 1 $\mathrm{ml}$ of the extract contains $50 \mathrm{mg}$ of crude garlic. Garlic fresh extract was orally administered to rats by the aid of a stomach tube fitted to a graduated syringe, at a dose level of $200 \mathrm{mg} / \mathrm{kg}$ body weight (Singh et al., 1995, Banerjee et al ., 2002).

\subsection{The Experimental design:}

Rats were randomly divided into seven equal groups each group contains 10 rats as follow: Group I: Normal control group for all experimental groups received saline only with standard diet. Group II: LCT intoxicated group received Lambdacyhalothrin (LTC) orally at dose of 10 $\mathrm{mg} / \mathrm{kg}$ b.wt. for 30 days. Group III: Thiodicarb intoxicated group received Thiodicarbat dose of $100 \mathrm{mg} / \mathrm{kg}$ b.wt. for 30 days. Group IV: LTC+ garlic protected group received LTC at dose of $10 \mathrm{mg} / \mathrm{kg}$ b.wt. + garlic extract at dose of $200 \mathrm{mg} / \mathrm{Kg}$ b.wt. for 30 days. Group V: Thiodicarb + garlic protected group: received thiodicarb at dose of $100 \mathrm{mg} / \mathrm{kg}$ b.wt. + garlic extract at a dose of $200 \mathrm{mg} / \mathrm{Kg}$ BWT for 30 days. Group VI: LTC+ garlic treated group: received Lambada-cyhalothrin (LCT) at a dose of $10 \mathrm{mg} / \mathrm{kg}$. b.wt. Orally for 30 days followed by daily oral administration of garlic extract of a dose level of 200 $\mathrm{mg} / \mathrm{kg}$.b.wt for another 30 days. Group VII: Thiodicarb + garlic treated group: received 
Thiodicarb at a dose of $100 \mathrm{mg} / \mathrm{kg}$.b.wt. orally for 30 days followed by daily oral administration of garlic extract of a dose level of $200 \mathrm{mg} / \mathrm{kg}$.b.wt for another 30 days

\subsection{Sampling:}

\subsubsection{Blood samples:}

Random blood samples were collected from all groups at the end of the experimental by cervical dislocation in sterile plastic tubes then centrifuged at 3000 r.p.m for $30 \mathrm{~min}$. and serum was aspirated and kept for the estimation of biochemical parameters .Were used for subsequent biochemical analysis.

\subsubsection{Biochemical analysis of blood :}

Serum alanine aminotransferase (ALT), aspartate amino transfrease (AST) activities and gamma glutamyle transferase (GGT) activities were determined according to the method described by Reitman and Frankel (Reitman, 1957). Urea was determined via Nesselerization method, described by Pratt, (1996) and Aitken et al., (2003). Serum creatinine was determined by Jaffe spectrophotometric method described by Pratt, (1996) and Aitken et al., (2003).Albumin and total protein were determined by the method described by (Lowry et al., 1951) and (Smith et al., 1985), respectively.

\subsubsection{Liver tissues specimens}

Rats were sacrificed by decapitation. The liver specimen quickly removed, cleaned by rinsing with cold saline and stored at $-20^{\circ} \mathrm{C}$. Liver tissues were minced into small pieces, homogenized in phosphate buffer $(\mathrm{pH}$ 7.4). The homogenates were centrifuged at 10,000 for 15 minute at $4^{\circ} \mathrm{C}$. The supernatants

\subsubsection{Determination of antioxidants enzymes in liver tissue:}

SOD activity in liver tissue was determined spectrophotometrically according to the method described by (Andersen et al., 1997).Reduced glutathion concentration (GSH) was determined according to the method described by Goldberg and Spooner (1984).CAT activity was determined according to the method described by(Aebi, 1984)

\subsection{Statistical analysis:}

Data were expressed as arithmetical mean \pm standard error of the mean (SEM). Least Significance Difference test (LSD) was carried out at a significant probability level of $p<0.05$. Analyses of variance (ANOVA) were conducted to obtain the significance of the treatment effect within each group and to establish significant differences among groups (Milliken, 1990).

\section{RESULTS}

Results in table (1) showed that Serum ALT\&AST and GGT activities are significantly increased in pesticides treated groups (1\&2) and serum Creatinine \& Urea concentration are markedly increased while serum albumin and total protein are significantly decreased as compared with the normal control group (1). However, administration of garlic extract along with pesticides or after administration of pesticides provides significant protective agents against changes in these biochemical parameters as in groups $(4,5,6 \& 7)$ as compared with normal control group. Results in table (2) showed that the antioxidants enzymes (SOD \& CAT) activities and GSH concentration in liver tissues was significantly decreased in rats treated with pesticide (groups 2\&3) compared to normal control group (1). The effect of garlic extract on levels of cellular antioxidant reservoir (SOD\&CAT and GSH) showed in groups $(4,5,6,7)$. Administration of garlic extract along with pesticides restored the level of GSH and other antioxidants enzymes in liver tissues near the normal values groups (4 \&5). Treatment the intoxicated rats with garlic extract in protected treated groups $(6 \& 7)$ showed also increased in antioxidants enzymes activities of (CAT \& SOD) and 
Table (1): Protective effect of garlic extract on some hepato-renal function in pesticides intoxicated rats

\begin{tabular}{|c|c|c|c|c|c|c|c|}
\hline $\begin{array}{l}\text { Groups } \\
\text { Parameters }\end{array}$ & $\begin{array}{l}\text { ALT } \\
(\mathrm{U} / \mathrm{L})\end{array}$ & $\begin{array}{l}\text { AST } \\
(\mathrm{U} / \mathrm{L})\end{array}$ & $\begin{array}{l}\text { GGT } \\
(\mathrm{U} / \mathrm{L})\end{array}$ & $\begin{array}{l}\text { Albumin } \\
(\mathrm{g} / \mathrm{dl})\end{array}$ & $\begin{array}{l}\text { T. Protein } \\
(\mathrm{g} / \mathrm{dl})\end{array}$ & $\begin{array}{l}\text { Creatinin } \\
\mathrm{e} \\
(\mathrm{mg} / \mathrm{dl})\end{array}$ & $\begin{array}{l}\text { Urea } \\
(\mathrm{mg} / \mathrm{dl})\end{array}$ \\
\hline Group 1 & $\begin{array}{l}61.25 \pm 3.6 \\
1^{\mathrm{b}}\end{array}$ & $62.50 \pm 2.44^{\mathrm{e}}$ & $\begin{array}{l}40.83 \pm 2.41 \\
\mathrm{~cd}\end{array}$ & $\begin{array}{l}4.31 \pm 0.10 \\
\mathrm{~b}\end{array}$ & $\begin{array}{l}6.68 \pm 0.14 \\
\text { bc }\end{array}$ & $\begin{array}{l}0.94 \pm 0.03 \\
\mathrm{~b}\end{array}$ & $\begin{array}{l}16.00 \pm 0.96 \\
\text { a }\end{array}$ \\
\hline Group 2 & $\begin{array}{l}72.00 \pm 6.6 \\
3^{\mathrm{b}}\end{array}$ & $\begin{array}{l}100.86 \pm 5.5 \\
2^{\mathrm{f}}\end{array}$ & $\begin{array}{l}75.26 \pm 8.61 \\
\mathrm{e}\end{array}$ & $\begin{array}{l}3.30 \pm 0.17 \\
\text { a }\end{array}$ & $5.61 \pm 0.29^{\mathrm{a}}$ & $\begin{array}{l}1.69 \pm 0.34 \\
\mathrm{c}\end{array}$ & $\begin{array}{l}43.00 \pm 8.80 \\
\text { b }\end{array}$ \\
\hline Group 3 & $\begin{array}{l}60.88 \pm 7.1 \\
5^{\mathrm{b}}\end{array}$ & $\begin{array}{l}42.13 \pm 5.02^{c} \\
d\end{array}$ & $\begin{array}{l}42.29 \pm 8.11 \\
\text { d }\end{array}$ & $\begin{array}{l}3.53 \pm 0.50 \\
\text { a }\end{array}$ & $5.29 \pm 0.75^{\mathrm{a}}$ & $\begin{array}{l}2.21 \pm 0.42 \\
\mathrm{~d}\end{array}$ & $\begin{array}{l}60.05 \pm 9.78 \\
\mathrm{c}\end{array}$ \\
\hline Group 4 & $\begin{array}{l}34.50 \pm 3.3 \\
5^{\mathrm{a}}\end{array}$ & $91.80 \pm 1.40^{\mathrm{f}}$ & $\begin{array}{l}23.00 \pm 2.23 \\
\text { ab }\end{array}$ & $\begin{array}{l}4.36 \pm 0.09 \\
\mathrm{~b}\end{array}$ & $\begin{array}{l}6.92 \pm 0.10 \\
\mathrm{~b}\end{array}$ & $\begin{array}{l}0.77 \pm 0.06 \\
\mathrm{a}\end{array}$ & $\begin{array}{l}21.40 \pm 1.66 \\
\mathrm{a}\end{array}$ \\
\hline Group 5 & $\begin{array}{l}40.30 \pm 3.9 \\
6^{a}\end{array}$ & $\begin{array}{l}27.00 \pm 3.78^{a} \\
\text { b }\end{array}$ & $\begin{array}{l}26.87 \pm 2.64 \\
\text { ab }\end{array}$ & $\begin{array}{l}4.51 \pm 0.12 \\
\mathrm{~b}\end{array}$ & $7.21 \pm 0.08^{c}$ & $\begin{array}{l}0.60 \pm 0.08 \\
\text { a }\end{array}$ & $\begin{array}{l}21.10 \pm 1.92 \\
\text { a }\end{array}$ \\
\hline Group 6 & $\begin{array}{l}35.70 \pm 5.4 \\
0^{\mathrm{a}}\end{array}$ & $\begin{array}{l}34.60 \pm 4.94^{b} \\
c\end{array}$ & $\begin{array}{l}24.80 \pm 3.28 \\
\text { ab }\end{array}$ & $\begin{array}{l}4.24 \pm 0.12 \\
\mathrm{~b}\end{array}$ & $\begin{array}{l}6.91 \pm 0.19 \\
\mathrm{bc}\end{array}$ & $\begin{array}{l}0.83 \pm 0.08 \\
\mathrm{a}\end{array}$ & $\begin{array}{l}21.50 \pm 2.10 \\
\mathrm{a}\end{array}$ \\
\hline Group 7 & $\begin{array}{l}30.20 \pm 3.9 \\
1^{\mathrm{a}}\end{array}$ & $20.60 \pm 1.90^{\mathrm{a}}$ & $\underset{\mathrm{a}}{16.78 \pm 2.17}$ & $\begin{array}{l}4.28 \pm 0.08 \\
\mathrm{~b}\end{array}$ & $\begin{array}{l}6.90 \pm 0.10 \\
b c\end{array}$ & $\begin{array}{l}0.57 \pm 0.10 \\
\text { a }\end{array}$ & $\begin{array}{l}15.50 \pm 0.95 \\
\text { a }\end{array}$ \\
\hline $\begin{array}{l}\text { L.S.D. } \\
0.05\end{array}$ & 12.74 & 10.23 & 10.45 & 0.47 & 0.69 & 0.40 & 9.62 \\
\hline
\end{tabular}

Data are presented as (Mean \pm S.E).SE: Standard error. a, b, c: Mean values with different superscript letters in the same column are significantly different at $(P \leq 0.05)$.

Table (2): Protective and treatment effect of garlic extract on liver tissue SOD and CAT activities and GSH concentrations in pesticides intoxicated rats.

\begin{tabular}{llll}
\hline Animal groups & $\begin{array}{l}\text { SOD } \\
(\mathrm{K} / \mathrm{g} \text { tissue })\end{array}$ & $\begin{array}{l}\text { GSH } \\
(\mathrm{mg} / \mathrm{g} \text { tissue })\end{array}$ & $\begin{array}{l}\text { CAT } \\
(\mathrm{K} / \mathrm{g} \text { tissue })\end{array}$ \\
\hline Group 1 & $21.98 \pm 0.88^{\mathrm{de}}$ & $31.06 \pm 2.92^{\mathrm{abc}}$ & $31.25 \pm 1.22^{\mathrm{d}}$ \\
Group 2 & $13.79 \pm 0.73^{\mathrm{a}}$ & $33.26 \pm 2.05^{\mathrm{abc}}$ & $16.84 \pm 0.87^{\mathrm{ab}}$ \\
Group 3 & $13.60 \pm 0.75^{\mathrm{a}}$ & $32.73 \pm 1.89^{\mathrm{abc}}$ & $14.33 \pm 0.95^{\mathrm{a}}$ \\
Group 4 & $21.21 \pm 1.05^{\mathrm{de}}$ & $34.49 \pm 2.92^{\mathrm{bc}}$ & $18.31 \pm 1.43^{\mathrm{bc}}$ \\
Group 5 & $23.37 \pm 2.17^{\mathrm{e}}$ & $37.41 \pm 2.39^{\mathrm{c}}$ & $20.87 \pm 1.08^{\mathrm{c}}$ \\
Group 6 & $17.38 \pm 1.34^{\mathrm{bc}}$ & $30.30 \pm 2.35^{\mathrm{ab}}$ & $17.29 \pm 1.25^{\mathrm{abc}}$ \\
Group 7 & $21.21 \pm 1.05^{\mathrm{de}}$ & $30.62 \pm 4.15^{\mathrm{ab}}$ & $18.31 \pm 1.43^{\mathrm{bc}}$ \\
L.S.D. at 0.05 & 3.60 & 6.97 & 3.57 \\
\hline
\end{tabular}

Data are presented as (Mean \pm S.E).SE: Standard error. a, b, c: Mean values with different superscript letters in the same column are significantly different at $(P \leq 0.05)$.

GSH concentration in liver tissues to the normal values as in normal control group (1).

\section{DISCUSSION}

The obtained data in table (1) revealed that, administration of thiodicarb and lambada- cyhalothrin to normal rats exhibited a significant increase in serum (GGT, AST \& ALT) activities and marked decreased in serum albumin and total protein concentration when compared to normal control group. Among the enzymes usually determined to evaluate hepatic function, GGT\&ALT is considered by many authors 
to be a reliable biomarker closely involved in the establishment of oxidative stress damage (O”zer et al., 2008). These enzymes have a central role in glutathione hepatic resynthesis. Moreover, as suggested by (Lim et al., 2004), it has an inverse relationship with the levels of many other antioxidants. Arnal et al., ( 2011) observed that GGT is more sensitive than other enzymes (AST and ALT). In addition, these enzymes are positively correlated with $\mathrm{LDH}$, total copper and non ceruloplasmin-bound copper $(\mathrm{NCBC})$ and is negatively correlated with the production of albumin. GGT has been used as a biomarker of pesticideinduced liver damage, and other researchers have demonstrated an association between increased activity of this enzyme and reduced antioxidant ability in rats (Lim et al.,2004) and humans (L'opez et al.,2007). Biological significance of enzymesdependent lipid peroxidation in vivo might be multifold. It is conceivable that the prooxidant effects of GGT activity are normally balanced by its established role in favoring the cellular uptake of precursors for GSH resynthesizes. Thus allowing the reconstitution of cellular antioxidant defense (Banerjeeet a1., 1999). The increased serum (GGT) activity has been attributed to the significant tissue injury provoked by pesticides, even at low doses employed in this study. When the liver cell plasma membrane is damaged, a variety of enzymes normally located in the cytosol are released into blood stream (Astiz et al.,2009).However, administration of garlic extract to pesticides intoxicated rats exhibited a significant decrease in GGT activity compared with Pesticides groups. It has been hypothesized that one of the principal causes of leakage of cellular enzyme into plasma is hepatic injury as reported by L'opez et al., (2007). The recorded results may be related to antioxidant activity of sulfhydryl compounds and its radical scavenging capacity to free radicals produced due to metabolism of carbamates and perythroids compounds by cytochrome P450 (Hazarika et al., 2003). These radicals increase the rate of lipid peroxidation, increased membrane rigidity, osmotic fragility, decreased cellular deformation, reduced cellular survival, and membrane fluidity (Comporti, 1985). Administration of antioxidants restores the imbalance in antioxidant defense mechanism and preserves the structural integrity of the hepatocellular membrane against free radicals (Mahmoud, 2011).

The obtained data in table (2) revealed that, administration of thiodicarb and lambadacyhalothrin to normal rats exhibited a decrease in Liver (GSH, SOD and CAT) activities when compared to normal control group. Carbamates and perythroids pesticides are most widely used in agriculture today, and have been known to cause symptomatic changes that arise through the inhibition of acetylcholine esterase, a key enzyme in neurotransmission (Altuntaset al., 2002). These pesticides have a highly efficient rate of absorption and following absorption, are widely distributed among various tissues. Exposure to these pesticides has postulated a putative role for the generation of free radical during the process (Dorval et al., 2003). The liver plays a central role in the homeostasis of $\mathrm{GSH}$, a physiologically important non-protein thiol in conjunction with GPx and GST comprises the GSH redox cycle that maintains the redox status of tissues and protects structural and regulatory proteins against Reactive oxygen species (ROS) - induced damage (Lu et al., 1999). Carbamates and perythroids pesticides are metabolized by liver microsomal enzymes to a variety of metabolites, which are susceptible to conjugation for proper elimination. Pesticides intoxication induces a derangement of antioxidant mechanisms of the liver cells, including decreased superoxide dismutase and catalase activities and alteration in reduced glutathione content leading to depressed GSH/GSSG ratios. Depletion of GSH and GSHdependent enzymes may shift the 
physiological balance of the cellular redox status in pesticide-treated rats leading to adverse effects on crucial thiol group in biological proteins favoring oxidative damage (Lu, 1999).

The recorded results may be attributed to the utilization of GSH in the metabolism of pesticides through GST. The study of (Silva, 2006) revealed that thiodicarb and lambada-cyhalothrin increased the activity of GST by conjugation of GSH to pesticides in vivo. This could be understood in view of the fact that some pesticides (carbamates and prethroids) consume GSH through GST catalyzed reaction as a major way of detoxification of these chemicals (Almeida et al., 1997).This observation is in accordance with other human studies (Panemangalore et al., 1999)and may result from the oxidative stress induced by pesticide exposure (Gultekin et al., 2001). A lower SOD activity favors the accumulation of oxygen free radicals in erythrocytes, and other cells, leading to tissue damage as a result of oxidative binding of key intracellular molecules containing thiol groups and lipid peroxidation of biological membranes, which might be of greatest importance in the cytotoxicity of pesticides and can be eventually responsible for cellular death. These data also indicate that SOD may be used as a biochemical marker of exposure (and/or effect) to pesticides for the surveillance of workers long-term exposed to these compounds.

Liver catalase activity (CAT) was significantly decreased, indicating that the higher exposure to pesticides the less enzyme activity. A mechanistic explanation for this finding is that the generated oxygen radicals might inhibit thiol groups of CAT (Kono and Fridovich, 1982)and thus the resultant excess in hydrogen peroxide may further inhibit SOD although the precise mechanism involved merits further research. This finding is consistent with the lower CAT and SOD activities observed in erythrocyte of patients acutely poisoned by dipterex, an organophosphorous insecticide (Zhou et al., 2004). In addition, the utilization of PPE(personal protective equipment) during the spraying of pesticides was associated with higher CAT activity, indicating that these devices limit the absorption of pesticides, thus minimizing the risk of interacting with blood CAT.

Treatment with aqueous garlic extract effectively reduced the combination of pesticide induced oxidative damage during the pesticides administration and enhanced the antioxidant enzymes levels in liver of rats. The results of this study further substantiate and add to the extensive literature in support of the myriad physiologic effects of garlic (Borek, 2001). Several plant products, including garlic allium components have been reported to modulate the levels of and antioxidants enzymes (Egen-schwind et al., 1992). Raw garlic contains a number of potential antioxidant compounds including organosulfur compounds, allicin that have anticarcinogenic properties (Lee et al., 2002). The enhancing effect of garlic on reduced glutathione (GSH) and phase II enzymes such as glutathione peroxidase (GPx) and glutathione-S-transferase (GST) may be considered as a generalized electrophilic counteractive response evoked by most chemo preventive agents. Modulation of LPO, enhancement of GSH and GPx together with elevation of GST are major mechanisms by which garlic exerts its chemo preventive effect (Kandarkar et al., 1996) .Extensive evidence also point to the ability of ally sulfides from garlic to suppress tumor proliferation both in vitro and in vivo (Sarkar et al., 2001). Moreover, the obtained results suggest that the pre and post treatment with garlic extract potentially reinforces the GSH/GST detoxification system and diminishes the oxidative stress induced by exposure to the combined dose of the pesticide.

From the obtained results, it could be concluded that thiodicarb and lambadacyhalothrin intoxicated rats extensively alters and induced disturbances in enzymatic and non-enzymatic antioxidant 
system in liver tissues. Moreover, garlic extract administration efficiently protects liver from deleterious effect of oxidative stress induced by these pesticides. This study suggests that, garlic extract may be effective in improving oxidative stress through its powerful antioxidant activity.

\section{Acknowledgement}

Special thanks for center of excellence in scientific research (CESR), faculty of veterinary medicine, Banha University, that funded by management supporting excellence (MSE) and Benha University.

\section{REFERENCES}

Abdollahi, M., Mostafalou, S., Pournourmohammadi, S., Shadnia, S. 2004. Oxidative stress and cholinesterase inhibition in saliva and plasma of rats following subchronic exposure to Malathion. Comparative Biochemistry and Physiology Part C. 137:29-34.

Aebi, H. 1984. Catalase in vitro. Methods Enzymol. 105:121-126.

Aitken, M.M, E. Hall, W.M, Allen, L. Scott and J. LDevot. 2003. Liver- related biochemical changes in the serum of dogs being treated with phenobarbitone. Vet. Record. 153: 13-16.

Akhgari, M., Abdollahi, M., Kebryaeezadeh, A., Hosseini, R., Sabzevari, O. 2003. Biochemical evidence for free radical induced lipid peroxidation as a mechanism for subchronic toxicity of malathion in blood and liver of rats. Hum. Exp. Toxicol. 22:205-211.

Almeida, M.G., Fanini, F., Davino, S.C., Aznar, A.E., Koch, O.R., Barros, S.B.M. 1997. Pro- and anti-oxidant parameters in rat liver after short-term exposure to hexachlorobenzene. Hum. Exp. Toxicol. 16:257-261.

Altuntas, I., Delibas, N. and Sutcu, R. 2002. The effects of organophosphate insecticide methidathion on lipid peroxidation and antioxidant enzymes in rat erythrocytes: role of vitamins E and C. Hum. Exp. Toxicol. 21(13):681-5.

Andersen, H., Nielsen, J., Nielsen, F., Grandjean, P. 1997. Antioxidative enzyme activities in human erythrocytes. Clin. Chem. 43:562568.

Arnal, N., Astiz, M., deAlaniz, M. J. T., Marra, C. A. 2011. Clinical parameters and biomarkers of oxidative stress in agricultural workers who applied copper-based pesticides. Ecotoxicology and Environmental Safety. 74:1779-1786

Astiz, M., Maria, J.T., Carlos, A. M. 2009a. The impact of simultaneous intoxication with agrochemicals on the antioxidant defense system in rat. Pesticide Biochemistry and Physiology. 94: 93-99.

Aslan, A., Cemek, M., Eser, O., Altunbas, K., Buyukokurog lu, M. E., Cosar, M., Bas, O., Ela, Y., Fidan, H. 2009. Does dexmedetomidine reduce secondary damage after spinal cord injury? An experimetal study, Eur. Spine J. 18:336-344.

Balali-Mood M., Balali-Mood K. 2008. Neurotoxic disorders of organophosphorus compounds and their managements, Arch. Iran. Med. 11: 65-89.

Banerjee, B. D., Seth, V., Bhattacharya, A., Pasha, S.T., Chakraborty, A. K. 1999. Biochemical effects of some pesticides on lipid peroxidation and free-radical scavengers. Toxicology Letters. 107:33-47.

Banerjee SK, Sood S, Dinda AK, Das TK, Maulik SK. 2002. Chronic oral administration of Row garlic protects against isoproterinol- induced myocardial necrosis in rat. Life Sci. 13:1509-18.

Beutler, E., Duron, O., Kelly, B. M.1963. Improved method for determination 
for liver glutathione. J. Lab. Clin. Med. 61:882- 888 .

Betrosian A. Balla M. Kafiri G. Kofinas G. Makri R. andKakouri A. 1995. Multiple system organ failure from organophosphate poisoning. J. Clin. Toxicol. 33 (3): 257-260.

Borek, C. 2001. Antioxidant health effects of aged garlic extract. J .Nutr. 131: $1010 \mathrm{~S}-1015 \mathrm{~S}$.

Comporti, M. 1985: Lipid peroxidation and cellular damage in toxic liver injury, Lab. Invest. 53:599-603.

Dapkevicius, A., van Beek, T. A., Lelyveld, G. P., van Veldhuizen, A., de Groot, A., Linssen, J. P. H., Venskutonis, R. 2002. Isolation and structure elucidation of radical scavengers from Thymus vulgaris leaves. J. Nat. Prod. 65:892-896.

Dorval, J., Hontela, A. 2003. Role of glutathione redox cycle and catalase in defense against oxidative stress induced by endosulfan in adrenocortical cells of ranbow trout (Oncorhynchusmykiss). Toxicol. Appl. Pharmacol. 15. 192(2): 191200.

Egen-schwind, C., Eckard, R. and Kemper, F.H. 1992. Metabolism of garlic constituents in the isolated perfused rat liver. Planta. Medica. 58:301-305.

Elias, M.A., Saif, M.A. 2009. The protection effect of vitamins A, C, and $\mathrm{E}$, against the potential toxicity of Methidathion on blood factors in male rabbits. Yem. J. Biol. Sci. 5(1):133136.

Goldberg DM, Spooner RJ. 1984. Glutathione reductase. In: Bergmeyer HU (ed). Methods in Enzymatic Analysis. Verlag Chemie: Basel. pp. 258-265.

Gultekin, F., Delibas, N., Yasar, S., Kilinc, I. 2001. In vivo changes in antioxidant systems and protective role of melatonin and a combination of vitamin $\mathrm{C}$ and vitamin $\mathrm{E}$ on oxidative damage in erythrocytes induced by chlorpyrifos-ethyl in rats. Arch. Toxicol. 75: 88-96.

Halliwell, B. and Gutteridge B.M. 1985. The chemistry of oxygen radicals and other oxygen-derived species.In: Free radicals in biology and medicine.New-York, Oxford University Press. pp. 20-24.

Hazarika, A., Sarkar, S. N., Hajare, S., Kataria, M., Malik, J. K. 2003. Influence of malathion pretreatment on the toxicity of anilofos in male rats: a biochemical interaction study. Toxicology. 185:1-8.

Henry, R. J. 1974. Colorimetric assay for the determination of Cholinesterase in serum and plasma. Clin. Chem., Principle and Tech. Harber u. Row Puplishers Inc. 1: 917-925.

Kandarkar, S.V. and Sawant, S.S. 1996. The effect of vitamin $\mathrm{C}$ and hamster cheek treated with water-soluble 4nitroquinidine-Ioxide (4Nos). Oral Oncology. 3213: 230-237.

Kono, Y., Fridovich, I. 1982. Superoxide radical inhibits catalase. J. Biol. Chem. 257:5751-5754.

Kumar, S.S., Shankar, B., Sainis, K. B. 2004. Effect of chlorophyllin against oxidative stress in splenic lymphocytes in vitro and in vivo. Biochimicaet Biophysica Acta. 1672: 100-111

L'opez, O. A. F., Hernandez, L., Rodrigo, F., Gil, G., Pena, J. L., Serrano, T., Parr'on, E., Villanueva, A. 2007. Changes in antioxidant enzymes in humans with long-term exposure to pesticides. Toxicology Letters. 171:146-153.

Lee, E.S., Steinar, H. and Len, R. 2002. Thioallyl compound protective inhibitors of cell proliferation. Biochem. Biophy. Archiv. 1221:7377.

Lim, J. S., Yang, J. H., Chun, B. Y., Kam, S., Jacobs, D. R., Lee, D. H. 2004. Is serum glutamyl transferase inversely associated with serum antioxidants as 
a marker of oxidative stress? Free Radic. Biol. Med. 37:1018-1023.

Lowry, O.H., N.J. Rosebrough, A.L. Farr, and R.J. Randall 1951 Protein Measurement with the Folin Phenol Reagent. J. Biol. Chem. 193: 265-275

Lu, S.C.1999. Regulation of hepatic glutathione synthesis: current concepts and controversies. FASEBJ. 13:1169-1173.

Mahmoud, A.M. 2011. Influence of rutin on biochemical alterations in hyperammonemia in rats. Experimental and Toxicologic Pathology. 4: 40-43.

Milliken GA, Johnson DE.1990: Analysis of Messy Data. Volume1: Designed Experiments. Belmont, CA, Life time learning. 1: 20-28.

O“zer, S., Ayfer, T.,G“ ulden, O., Sule, C., Gazi, C., Nursal, G., G” oksel, S. 2008. Protective effect of resveratrol against naphthalene-induced oxidative stress in mice. Ecotoxicol. Environ. 14: 256-261.

Panemangalore, M., Dowla, H.A., Byers, M.E. 1999. Occupational exposure to agricultural chemicals: effect on the activities of some enzymes in the blood of farm workers. Int. Arch. Occup. Environ. Health. 72:84-88.

Pratt, P.W. 1996. Laboratory Procedures for Veterinary Techniques. $3^{\text {rd }}$ Edn, Mosby, Philadelphia, pp. 98-99.

Reitman S, Frankel S.A. 1957. Colorimetric method for the determination of serum glutamic oxaloacetic and glutamic pyruvic transaminase. Am $\mathrm{J}$ Clin. 28:56-63.

Sarkar, A.E., Bhaduri, A. 2001. Tea is a powerful chemopreventive of reactive oxygen and nitrogen species. Comparison with individual catechin constituents of green tea. Biochem. Biophy. Res. Commum. 284:173178.

Sener, G.; Satyruglo, H.; Ozer-Sehilrli, A. \& Kacmaz, A. 2003 - Protective effect of aqueous garlic extract against oxidative organ damage in a rat model of thermal injury. Life Sci. 73: 81-91.

Silva, A.P., Meotti, F.C., Santos, A. R. S., Farina, M. 2006. Lactational exposure to malathion inhibits brain acetylcholinesterase in mice. Neuro Toxicology. 27:1101-1105.

Smith, P.K. 1985. Measurement of Protein Using Bicinchoninic Acid. Anal. Biochem. 150:76-85.

X.-M. Liu, J.-Z. Shao, L.-X. Xiang, X.-Y. Chen. 2006. Cytotoxic effects and apoptosis induction of atrazine in a grass carp (Ctenopharyngodonidellus) cell line. Environmental Toxicology. 21(1): 80-89.

Zhou, J.F., Zhou, W., Zhang, S.M., Luo, Y.E., Chen, H.H. 2004. Oxidative stress and free radical damage in patients with acute dipterex poisoning. Biomed. Environ. Sci. 17:223-233. 